\begin{tabular}{lcr}
\hline & ANNALES \\
& UNIVERSITATIS MARIAE CURIE-SKŁODOWSKA & \\
VOL. I & LUBLIN - POLONIA & 2016 \\
\hline
\end{tabular}

\title{
Иеонид Смиловицкий
}

Tel Aviv University

\section{Отношение к Холокосту в Советском Союзе и современной Бемаруси}

В течение всего послевоенного периода вплоть до начала горбачевской перестройки тема Катастрофы евреев на территории СССР не звуча а. О трагеАии евреев, пострадавших от рук нацистов в гоАы второй мировой

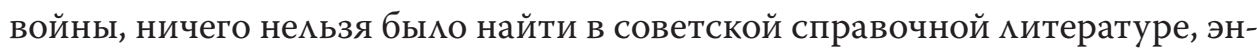
цикмопеАиях, учебниках, научных изданиях. Масштабы трагеАии Холокоста, примеры жестокости и саАизма и в то же время героизм оАиночек, которые вопреки всякой могике, пренебрегая смертецьным риском, которому подвергали себя и свои семьи, спаса и евреев, замацчивались. О геноциде евреев не принято было говорить вслух. Об этом не знали учителя истории и их ученики, студенты исторического факультета и их преподаватели, и просто человек с улицы.

За пределами Советского Союза, где источники информации были общедоступны, вопрос о природе Холокоста кажется наивным. ОАнако и сегодня на Западе многие не понимают, почему советское государство не было заинтересовано в распространении правды о Холокосте, если евреев убивали нацисты, а Красная армия их защищала? Почему нужно было умацчивать о героизме советских евреев в тылу и на фронте, почему об этом не вспоминаци с официальных трибун, в публицистике или исторических исследованиях? Стоит $и$ после этого уАивцяться, что на уровне советского обыденного сознания наАолго закрепи ся миф о том, что евреи «воева и в Ташкенте»? 
Ответ на эти вопросы я нашец, когАа начац свое вхожАение в израицьскую науку в начале 1990-х годов. Аля этого мне потребовалась необходимая сумма знаний, знакомство с разными подходами в освещении истории второй мировой войны. Но самое главное оказацось то, что я пришел к пониманию этой проблемы через опыт собственных исслеАований. Итак, в чем же бымо демо?

Правда о Холокосте бросала тень на весь советский режим. Неготовность страны к войне с Германией, неудачное начало боевых Аействий, проигранные сражения и отступление, сотни тысяч пленных, пренебрежительное отношение к гражданскому населению (вывоз в первую очередь материа ьных ценностей, оборудования и сырья, а уже потом мюдей), некомпетентность принятия решений и т. А.

ВслеА возникали Аополнительные вопросы: Что преАстав яя а собой национацьная политика советского государства? Почему был взят курс на русификацию, подавление национальной кумьтуры, траАиции, преследование религии, запрет иврита и отказ от языка идиш? Насколько испытание войной выдержала «сталинская Аружба народов»? Нужно бымо объяснить, почему нацисты избрахи именно евреев своей главной мишенью. Почему руководители Рейха утвержАахи, что они ведут войну не против России и русского народа, а против ее руководителей, попавших в поАчинение к евреям? Поэтому, моц, в интересах русского народа сбросить иго жиАобольшевиков, т.е. коммунистов, и Аобровольно присоеАиниться к освобоАительному Авижению Гитлера.

Советская пропаганда отреагироваца на этот тезис Геббельса совершенно иначе, чем это можно было ожидать. Евреев никто не собирался спасать. Они как народ были обречены на поголовное уничтожение по национацьному признаку. ОАнако, несмотря на это, со стороны советского государства ничего сделано не было, поскольку тогАа косвенно подтвержАался тезис нацистов о том, что Германия воюет с евреями, а не против русского народа. Сталин попац в умело расставленную мовушку. Выделить евреев как группу риска, означа о поставить под сомнение принцип интернациона изма, положенный в основу советской иАеологии.

Советское руководство опасацось, что выделение евреев из всех советских народов, за искмючением цыган, которых нацисты уничтожаци наряду с евреями, качнет маятник национа изма в внутри страны, что бы о чревато серьезными последствиями. Напомним, что в начале сентября 1941 г. вся территория Беларуси была захвачена немцами, а планы по эвакуации мирного насемения и материальных ценностей были не выполнены. Мимхионы юАей оказалась на оккупированной врагом территории, совершенно не 
преАставцяя свое будущее. Вместо этого советская пропаганда призываца при отходе сжигать и разрушать за собой все, что можно, ничего не оставАяя врагу. При этом совершенно не принималось во внимание, что тем самым мюдей обреками на голодную смерть.

Что означа оо Аля советского государства признать правАу о Холокосте?

Обнародовать подиинную цену победы и объяснить, почему она так велика. Признать ошибки во внутренней и внешней политике, массовые репрессии и неготовность к войне, несостоятемьность национацьной помитики - все это неизбежно поднимало вопрос о законности советской власти. Это быма мина замеАленного Аействия.

Правда Хомокосте обнажама широкие масштабы комлаборации. Как

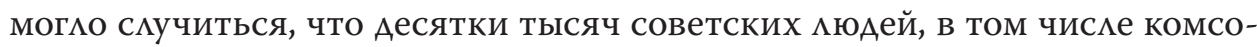
мольцев и коммунистов, бывших партийных работников, солАат и офицеров Красной армии, перешки на сторону врага, выдаваци и убиваци евреев, захватыва и их имущество и Аома.

Что выигрывацо советское государство, скрывая правАу о Холокосте?

Сохранение тотацитарного строя, виАимости интернационакизма, соблюдения демократии, свободы мичности, прав человека, формальное равенство перед законом, а также сокрытие цены, т.е., михмионов потерянных жизней и итогов созиАательного труда в течение Аесятилетий, борьбу с инакомыслием, обеспечение закрытости советского общества и полного контроця наА сознанием и повеАением своих гражАан. Понятно, что при таких обстоятельствах правда о Холокосте становицась неугоАной.

Советская власть относицась к евреям, как к надежным исполнителям. Еврейская молодежь воспитывацась в духе интернационацизма, в отрыве от национамьной традиции, культуры, рекигии и языка. За поскушание полагались материацьные блага и Аолжности, но только на начацьном и среАнем уровне. Как только каАры из титульных наций подрастали, евреев отоАвигали на заАний план под надуманными преАлогами. В то же время формально на их права никто не покушался. Евреи вынуждены были жить Авойной жизнью (на работе и Аома). В 1970-е годы, когда началась волна эмиграции из Советского Союза поА преАлогом воссоеАинения семей, роАилась шутка: к Авум евреям подходит третий и говорит - я не знаю, о чем вы говорите, но ехать надо (имелось в виду в Израиль).

Мы все еще не знаем правды о Холокосте. Трагедия слишком велика, это пропасть без Ана. В то же время можно безошибочно указать на причины, по которым эта правда доцгие годы замацчивалась.

Отношение к проблеме Холокоста в годы второй мировой войны - это камертон, который помогает опреАемить, насколько наука независима от 
политики. Насколько она способна формулировать выводы, которые не обязательно отвечают устоявшимся канонам, оказывать влияние на общественное мнение и застав ять прислушиваться политиков.

В наши Ани на постсоветском пространстве правду о Холокосте не скрывают. Она Аоступна всем, кто хочет понять природу этого страшного явления, найти ответы на волнующие вопросы. Важность этого события общепризнанна. Не случайно ООН с 2005 г. отмечает Международный Аень памяти жертв Хомокоста, приуроченный к освобожАению советскими войсками концлагеря Освенцима в январе 1945 г. Инициаторами принятия этого важного решения выступили Израиль, США, КанаАа, Австралия, Россия, Украина, а их соавторами - более 90 государств мира.

ОАнако, если говорить о Беларуси, то в республике, одной из наиболее постраАавших в гоАы второй мировой войны, Ао сих пор отсутствует государственная концепция отношения к Холокосту.

Еврейское население Беларуси метом 1941 г., вместе с беженцами из Польши (после 1 сентября 1939 г.), состав яя 1 млн. чел., или 10\% насемения республики. После оккупации республики нацисты создали около 300 гетто (открытого и закрытого типа). В итоге Беларусь потеряла 800 тыс. евреев, которых замучили, расстреляли, сожгли к 1944 г.

Но сухая статистика не в силах сказать обо всем. Если принять во внимание, что Ао войны евреи состав яли не менее $60 \%$ городского насемения республики, а среди врачей, инженеров, агрономов, конструкторов, финансовых работников, художников, музыкантов, писателей, партийных и советских каАров - Ао 80\%, то виАно, сколько потеряла Беларусь в результате нацистской политики геноциАа.

Официально считается, что белорусы евреев не убивали, а спасали, что евреи были жертвами только нацистов, что евреи и белорусы одинаково пострадали от нацизма и поэтому преувеличенное внимание к истории Холокоста в Беларуси неуместно. Приходится сожалеть, что в современной Беларуси до сих пор на уровне исторического истэблишмента и госуАарственных структур (институт истории НАН, научные исследовательские центры, университеты, музеи, министерства и ведомства, имеющие отношение к гуманитарной сфере) отказываются замечать размичие между такими понятиями, как «террор» и «геноциА». Белорусов никогАа не убива^и по национальному признаку (геноциА). Все карательные операции нацистов в республике (террор), являлись акциями возмездия за поААержку партизанского Авижения, или Аля того, чтобы мишить партизан их базы. И в этом принципиахьная разница, которую, наконец, необходимо признать. 
Возможно, поэтому в респубцике отсутствуют плановые научные темы в Институте истории Национамьной Академии наук, исследовательских центрах и университетах, не проводятся ежегодные официацьные государственные церемонии поминовения Аня Хомокоста (на уровне Парламента и Правительства). Президент А.Г. Аукашенко за 20 лет посети мемориацьный комплекс «Яма» в честь Минского гетто (100 тыс. жертв) всего три раза $(1995,2000,2005$ гг.).

Как ни странно, но в современной Беларуси до сих пор отсутствуют государственные Еврейский музей, Музей Катастрофы евреев Бекаруси, Музей Минского гетто. Не выпускается ни оАин научный журнац, посвященный геноциду евреев Беларуси, не изАана ЭнцикцопеАия истории Хомокоста в Беларуси, ЭнцикмопеАии правеАников мира, уроженцев Беларуси. Не существует и государственная программа отражения тематики гетто в краевеАческих музеях республики и т. А. (слабые попытки восполнить этот пробел в новом Белгосмузее истории Великой Отечественной войны немьзя принимать в расчет).

История Холокоста не изучается в учебном процессе. Не исследованы отличительные особенности трагедии евреев Беларуси. Нет ответа на вопрос, как повция Холокост на Аемографическое, экономическое, научное и культурное развитие республики в послевоенный период? Насколько эхо Холокоста до сих пор ощущается по тем какунам, которые не устранены за счет Беларуси? Обо всем этом пора сказать в полный голос с официа ьной трибуны, поскольку в условиях современной Беларуси позиция государства необыкновенно важна.

Поэтому не нужно уаивмяться, что первые серьезные исследования, посвященные истории Холокоста на территории Беларуси были выполнены именно на Западе. Это сборники воспоминаний и свидетельств очевиАцев и участников событий, научные статьи и монографии (на иврите, идиш, польском, немецком и английском языках).

За послеАние 20 мет белорусские историки внесли немалый вкмаА в изучение названной проблемы. На сегодняшний день мы имеем обзорные работы по истории Холокоста в Беларуси Эммануима Иоффе, АавиАа Мемьцера, Евгения Розенблата, Ирины Еленской, Геннадия Винницы. Важные сборники Аокументов и материалов были изАаны при участии Раисы Черноглазовой, Марата Ботвинника, Вячеслава Селеменева, Инны Герасимовой и Ар.

ОАнако не будем скрывать, что все эти работы (статьи, книги, сборники Аокументов и даже Аиссертации) стали возможными только благодаря 
мичной инициативе самих исследователей. Государство не преАостав яя о им заказов, не выдавало грантов, не вкцючало в исследовате ьские программы, не спонсировало научные конкурсы. В учебных заведениях отсутствуют спецкурсы или специализации «История Холокоста в Беларуси», не проводятся научные конференции поА эгидой государственных ведомств.

Все это печально на фоне того, что уже сАелали сосеАи Беларуси в России, на Украине, в Молдове, в странах Балтии, не говоря уже о Германии, Польше, Болгарии, Румынии, Чехии и Словакии. В этих странах на исследования, посвященные Холокосту, выделяются немалые государственные среАства. Причем никого уговаривать не нужно, они заложены в бюАжет. Есть чему поучиться. Вопрос, почему в Беларуси не учатся? Не могут, не хотят или нет желания? Скорее всего, потому что современное белорусское руководство не виАит связи межАу трагеАией евреев Беларуси и нынешним состоянием республики (Ауховным, культурным, экономическим). Нет понимания того, как уроки прошлого вАияют на будущее Беларуси и ее народа. Это стоит принять, это стоит признать, это стоит исправить.

Проблематику Холокоста в Беларуси необходимо вкмючить в общий комплекс изучения истории Великой Отечественной войны в республике. Эта работа Аолжна иметь не только научный, но и образовательный характер, а финансирование обязано взять на себя государство. ПреАвижу ответ - денег нет ... Не могу согласиться. Прежде всего, необходима политическая воля, а решение найдется. Нужно начать, найдутся и спонсоры, но спонсорам важно отношение государства, четкое определение позиции, признание приоритета.

Своим отношением к истории Холокоста Беларусь подтверАит, что республика развивается в рамках европейского мышления. Что может быть важнее чувства уважения со стороны соседей? Ощущать себя равным и полноценным участником в семье европейских народов. Нравственные, политические и экономические дивиденды, которые неизбежно послеАуют, окупят все затраты. Изменение отношения в республике к истории Холокоста возАаст Аолжное памяти 800 тыс. евреев республики, которые так много сАелали Аля Беларуси.

3 декабря 2015 г., Иерусалим 

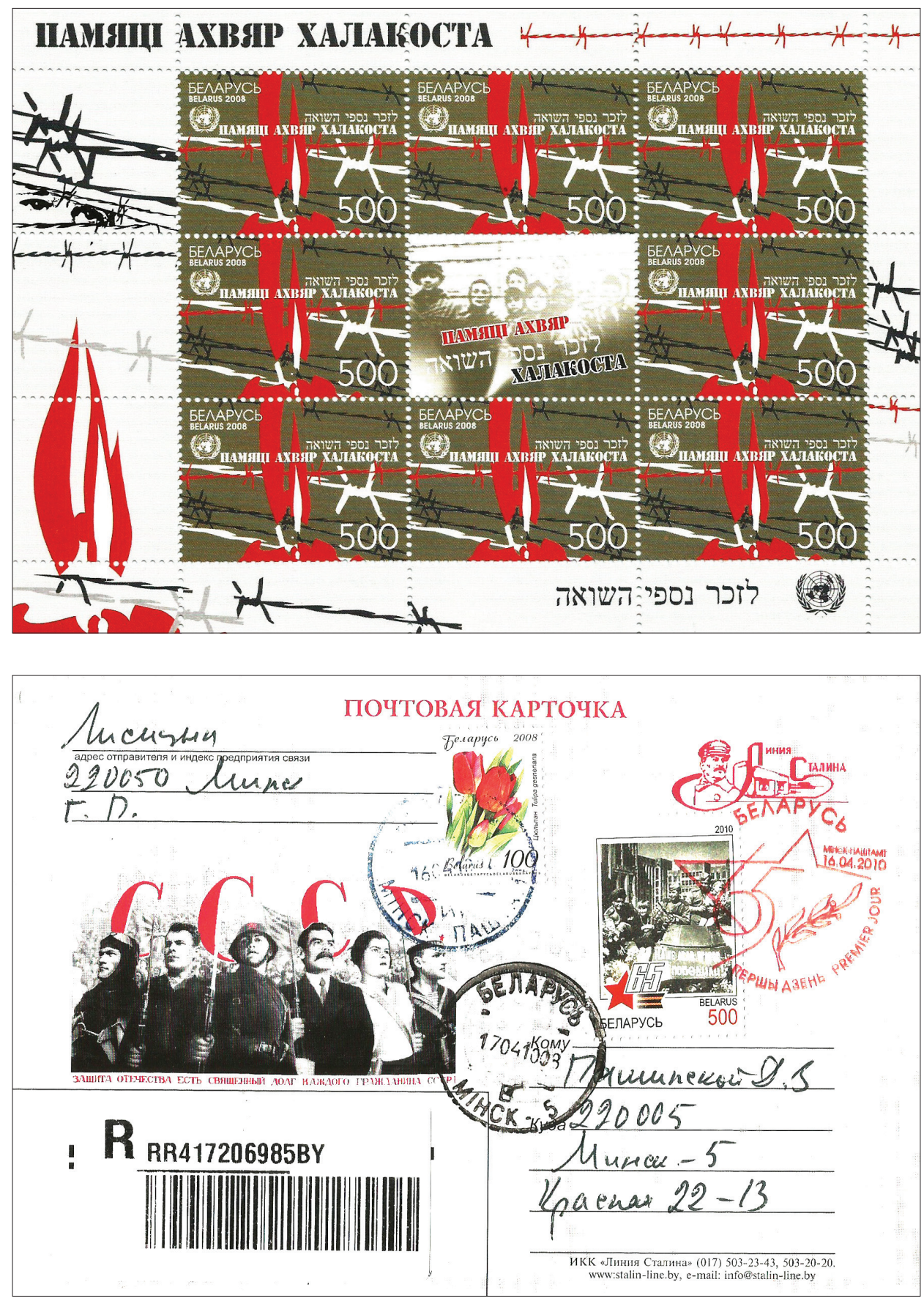


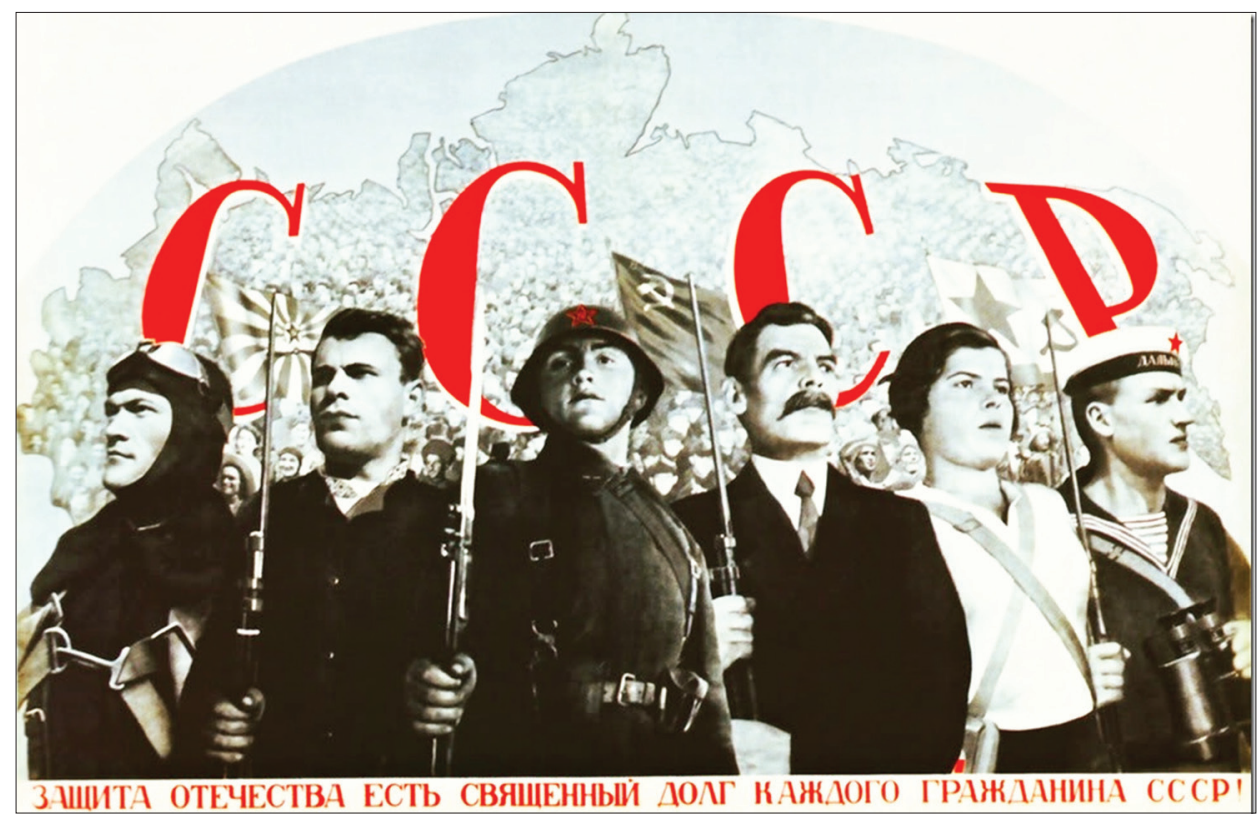




\section{Instrukcja dla autorów tekstów w „Annales Universitatis Mariae Curie-Skłodowska” - sectio „Balcaniensis et Carpathiensis”}

1. Długość tekstu artykułu: minimum 20 tys. znaków ze spacjami, z uwzględnieniem przypisów.

2. Długość tekstu recenzji: minimum 10 tys. znaków ze spacjami, z uwzględnieniem przypisów.

3. Teksty w wersji elektronicznej w formacie .doc należy przysyłać na adres sekretarza redakcji dr hab. Małgorzaty Podolak - podolakm@op.pl.

4. Redakcja przyjmuje teksty w językach: polskim, angielskim, rosyjskim, francuskim i niemieckim.

5. Zasady edytorskie

- niestosowanie wersaliku w zapisywaniu tytułu artykułu oraz części artykułu

- niestosowanie w tekście pogrubień i podkreśleń

- zapisywanie cytatów antykwą w cudzysłowach (bez stosowania kursywy)

- zapisywanie wyrazów obcojęzycznych (np. łacińskich, angielskich w tekście nieangielskojęzycznym, rosyjskich w tekście nierosyjskojęzycznym) kursywą, np. primo

- umieszczanie odsyłaczy do przypisów przed znakiem przestankowym

- podawanie po raz pierwszy pełnej nazwy organizacji lub instytucji, np. Organizacja Narodów Zjednoczonych

- podawanie po raz pierwszy osoby z pełnym imieniem, np. Lech Kaczyński

- zapisywanie w tekście polskojęzycznym nazw własnych w języku polskim, np. Organizacja Paktu Północnoatlackiego, Unia Europejska, Stany Zjednoczone Ameryki

- nieodmienianie skrótowców, np. PiS zamiast PiS-u

- zapisywanie dat: 25 X 2008 roku, 25 października, w październiku 2008 roku

- zapisywanie dekad słownie, np. w latach osiemdziesiątych

- stosowanie pauz bez spacji, np. 1945-1989.

6. Do artykułu należy dołączyć w języku polskim i angielskim streszczenie (do 500 znaków), słowa kluczowe oraz biogram autora (afiliacja, stanowisko, tytuł i stopień naukowy, adres elektroniczny i tradycyjny).

7. Materiały graficzne (zdjęcia, skany, mapy, diagramy) należy zamieścić w tekście oraz w osobnych plikach w formacie .jpg.; natomiast tabele należy przygotować w programie Word dla Windows i zamieścić tylko w tekście.

\section{Tabela 1}

Tytut tabeli czcionka 12 p.

\begin{tabular}{|l|l|l|l|l|}
\hline & & & & \\
\hline & & & & \\
\hline
\end{tabular}

Źródło: Opis bibliograficzny wg zasad obowiązujących w przypisach, czcionka 10 p. 
8. Formatowanie tekstu:

- czcionka tekstu głównego: Times New Roman 12

- czcionka tekstu w przypisach: Times New Roman 10

- interlinia 1,5

- podział tekstu na części.

9. Przypisy należy umieścić na dole strony, stosując skróty łacińskie (Ibidem, op. cit., Idem, Eadem).

10. W językach opartych na cyrylicy publikacje należy zapisywać w tekście głównym i w przypisach za pomocą cyrylicy, natomiast w bibliografii należy dokonywać latynizacji zapisu publikacji.

11. Obowiązkowe formy stosowane w przypisach:

- monografia ${ }^{1}$

- artykuł w pracy zbiorowej pod redakcją ${ }^{2}$

- artykuł w czasopiśmie naukowym ${ }^{3}$

- publikacja źródłowa w prasie (należy obowiązkowo podać datę dzienną oraz numer strony $)^{4}$

- akt prawny ${ }^{5}$

- źródło archiwalne ${ }^{6}$

- dokument elektroniczny w postaci tekstu naukowego ${ }^{7}$

- materiał źródłowy zamieszczony w internecie (należy podać podmiot odpowiedzialny za stronę lub nazwę strony, jedynie skrócony adres internetowy, tytuł dokumentu internetowego, dzień pozyskania danych) ${ }^{8}$.

12. Do artykułu należy dołączyć bibliografię, podzieloną na dwie części: źródła i piśmiennictwo naukowe.

13. Obowiązkowe formy stosowane w bibliografii:

- Kowalski J., Tytut publikacji, Oficyna Wydawnicza, Warszawa 2002.

- Nowak B., Tytut artykutu, [w:] Tytut pracy zbiorowej, red. N. Kowalczyk, Oficyna Wydawnicza, Lublin 2014.

- Piotrowski J., Tytut artykutu, „Czasopismo Naukowe”, 2005, nr 3.

- Nowakowski T., Tytuł artykułu, „Gazeta Codzienna”, 2 X 2013, nr 23.

- Nowak J., Tytut publikacji dostępnej w Internecie, http://adresinternetowy.pl.

- Strona internetowa UMCS, http://www.umcs.lublin.pl, „Materiały pomocnicze do nauczania historii”.

1 I. Nazwisko, Tytut monografii kursywa, Oficyna Wydawnicza, Warszawa 2010, s. xx.

2 I. Nazwisko, Tytut artykutu kursywa, [w:] Tytut pracy zbiorowej kursywa, red. I. Nazwisko, Oficyna Wydawnicza, Warszawa 2005, s. xx.

3 I. Nazwisko, Tytuł artykutu kursywa, „Tytuł Czasopisma”, 2008, nr 4, s. xx.

4 I. Nazwisko, Tytuł publikacji źródtowej kursywa, „Tytuł Gazety”, 23 IX 2013, nr 56, s. xx.

5 „Dziennik Ustaw”, nr xx, poz. xxx, „Ustawa o zasadach edytorskich z 23 I 2014 roku”, s. xx.

6 Archiwum Akt Nowych, Akta Partii Politycznych, sygn. 21/B/34, t. 3, „Tytuł dokumentu archiwalnego", k. 2.

7 I. Nazwisko, Tytut publikacji naukowej zamieszczonej w Internecie, adres elektroniczny, s. x, dostęp 23 VIII 2013.

8 Strona internetowa Wydziału Politologii, http://www.politologia.pl, „Tytuł dokumentu internetowego", dostęp 23 VIII 2013. 


\section{The rules of the reviews in "Annales Universitatis Mariae Curie-Skłodowska” - sectio „Balcaniensis et Carpathiensis”}

1. The editorial board enables the articles to be published once the text is prepared in concord with the scientific workshop and editorial rules stated in The instruction for the authors. The secretary of the editorial board is responsible for the formal evaluation of the article and informs the author of the text via electronic post about the decision about the permission or its lack.

2. To evaluate every article the Editorial Board calls two independent and competent reviewers (the reviewers do not have the same affiliation as the author of the text).

3. In case of the article written in the foreign language (another than Polish) at least one of the reviewers should be affiliated in an international institution placed in another state than the state the author of the text comes from.

4. Making reviews is confidential - the reviewer and the author of the articles do not know each other's identity before making the opinion and its sending to the Editorial Board.

5. The Editorial Board checks would-be conflict of interest between the reviewer and the author of the article.

6. The review has its written and electronic version and the conclusion finishes with the explicit recommendation to publish or reject the article.

7. The criteria of the formation of the opinion are placed in The sheet of the review; the Editorial Board rejects the reviews that do not meet these criteria in a formal and scientific sense. The sheet of the review is available in an electronic form on the website of the scientific journal.

8. In case of two contradictory opinion the editorial board calls the third reviewer.

9. The general conclusion, the evaluation of the text and the particular remarks are passed to the author of the article who is obliged to respond to them in electronic and written form. In a mutually excluding situation between the author and the reviewer concerning the particular remarks, the Editorial Board makes the decision about the necessity to take into account the particular remarks by the author formed in the recommended changes in the review.

10. The final decision about placing in the short-list or rejection of the article makes the Editor-in-chief. The Editor-in-chief might consult the Editorial Board in questionable cases.

11. The list of the reviewers cooperating with the Editorial Board is placed in every number of the journal and on the website of the scientific journal in an alphabetic list. 
К свеАению авторов текстов в „Annales Universitatis Mariae Curie-Skłodowska” - sectio „Balcaniensis et Carpathiensis”

1. Объем текста статьи: минимум 20 тыс. знаков, вкцючая пробелы и учитывая ссылки.

2. Объем текста рецензии: минимум 10 тыс. знаков, вкцючая пробелы и учитывая ссылки.

3. Тексты в электронном виде, расширение *doc, следует отправлять секретарю редакции, докт. н. Малгожате Подоляк, по адресу: annalescarbal@gmail.com

4. РеАакция принимает тексты на польском, английском, русском, французском и немецком языках.

5. ИзАательские требования

- не используется прописной шрифт в названии статьи и частей статьи

- не используются в тексте подчеркивания и утолщения

- цитаты записываются антиквой в кавычках (без использования курсива)

- иноязычные слова (напр., матинские, английские в неанглоязычном тексте, русские - в нерусскоязычном) записываются курсивом, напр., primo

- сноски к комментариям (ссылкам) размещаются переА знаком препинания

- при первом применении Аается полное название организации ими учреждения, напр., Организация ОбъеАиненных Наций

- при первом указании на мицо, имя и фамикия записываются полностью, напр., Аех Качиньски

- в польскоязычном тексте имена собственные записываются по-польски, в русскоязычном - по-русски, напр., Организация Североатлантического Аоговора (НАТО), Европейский союз, Евросоюз, СоеАиненные Штаты Америки

- аббревиатуры не скмоняются, напр., ПиС, относится к ПиС; ЕС, в ЕС

- дата записывается следующим образом: 25 X 2008 года, 25 октября, в октябре 2008 года

- декады записываются словами, напр., в восьмидесятые годы, в девяностых гоAаX

- используются паузы без пробелов, напр., 1945-1989

6. К статье следует приложить аннотацию на польском и английском языках (Ао 500 знаков), кцючевые слова и краткую информацию об авторе статьи (аффимиация, Аолжность, ученая степень, ученое звание, электронный и почтовый аАреса).

7. Графические материалы (фотографии, сканы, карты, диаграммы) следует разместить в тексте и отдельных файлах, расширение JPEG (.jpg.); таблицы же следует приготовить в редакторе Word Аля Windows и разместить Аишь в тексте статьи. 


\section{Таблица 1}

Название - кегль 12 n.

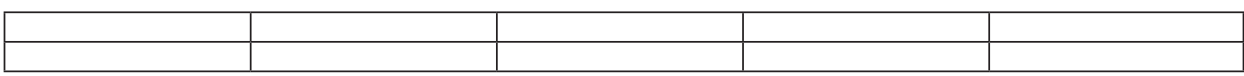

Источник: Библиографическое описание согласно правимам, которые обязывают в комментариях (ссылках), кегль 10 п.

8. Форматирование текста:

- текст статьи: кегль 12, гарнитура Times New Roman

- текст ссылки: кегль 10, Times New Roman

- межстрочный интервах 1,5

- разделение текста на (Аогические) части

9. Ссылки следует разместить в конце страницы, используя катинские сокращения (Ibidem, op. cit., Idem, Eadem).

10. Публикации на языках, в которых не используется матинский ацфавит, а кирилмические, греческие и иные источники, слеАует фиксировать киримлицей в случае текста статьи и ссылок; в библиографическом списке проводится матинизация записей.

11. При оформхении ссылок необходимо соблюдать нижеуказанные требования:

- монография ${ }^{1}$

- статья в сборнике под реА. ${ }^{2}$

- статья в научном журнале ${ }^{3}$

- публикация, основанная на источниках, в печати (в обязательном порядке следует указать Аневную Аату и номер страницы $)^{4}$

- правовой (нормативный) акт ${ }^{5}$

- архивный источник ${ }^{6}$

- электронный Аокумент в виде научного текста ${ }^{7}$

- основанный на источниках материа , размещенный в Интернете (следует указать субъект, ответственный за сайт или название сайта, сокращенный Интернет-адрес, название Интернет-документа, день получения данных) ${ }^{8}$

1 И. Фамилия, Название монограбии курсивом, Издательство, Варшава 2010, стр. хх.

2 И. Фамилия, Название статьи курсивом, [в:] Название сборника курсивом, И. Фамилия, Издательство, Варшава 2005, стр. хх.

3 И. Фамилия, Название статьи курсивом, «Название Журнала», 2008, № 4, стр. хх.

4 И. Фамилия, Название публикации, основанной на источниках, курсивом, «Название Газеты», 23 IX 2013, № 56, стр. хx.

5 «Законодательный вестник», № xx, п. хxх, «Закон об издательских требованиях от 23 I 2014 года», стр. хx.

6 Архив новых актов», Аокументы (Акты) политических партий, ш. 21/B/34, т. 3, «Название архивного Аокумента», .2.

7 И. Фамилия, Название научной публикации, помещенной в Интернете, электронный аАрес, стр. х, Аоступ 23 VIII 2013.

8 Интернет-сайт Факультета политологии, http://www.politologia.pl, «Название Интернет-Аокумента», Аоступ 23 VIII 2013. 
12. К статье примагается библиография, разделенная на Аве части - источники и научная митература.

13. Правима оформмения библиографии:

- Ковальски И., Название публикации, Издательство, Варшава 2002.

- Новак Б., Название статьи, [в:] Название сборника, реА. Н. Ковацьчик, Издательство, Аюблин 2014.

- Пиотровски Е., Название статьи, «Научный Журнам», 2005, № 3.

- Новаковски Т., Название статьи, «Газета Выборча», 2 Х 2013, № 23.

- Малик Й., Название Интернет-публикации, http://adresinternetowy.pl.

- Интернет-сайт УМКС, http://www/umcs/lublin.pl, «Вспомогательные материалы по обучению истории». 